\title{
Farming Efficiency and the Survival of Valuable Agro-Ecosystems: A Case Study of Rice Farming in European Mediterranean Wetlands
}

\author{
Andrés J. Picazo-Tadeo ${ }^{*}$, , Ernest Reig-Martínez ${ }^{2}$ and Vicent Estruch ${ }^{3}$ \\ ${ }^{1}$ Universidad de Valencia, Dpto. Economía Aplicada II, Avda dels Tarongers s/n, 46022 Valencia, Spain \\ ${ }^{2}$ Universidad de Valencia, Dpto. Economía Aplicada II, Avda dels Tarongers s/n, 46022 Valencia, Spain and Instituto \\ Valenciano de Investigaciones Económicas (IVIE), Guardia Civil, 22-2-1, 46020 Valencia, Spain \\ ${ }^{3}$ Universidad Politécnica de Valencia, Dpto. Economía y Ciencias Sociales, Escuela Superior de Ingenieros Agrónomos, \\ Camino de Vera s/n, 46022 Valencia, Spain
}

\begin{abstract}
Beyond the conventional role of providing food, rice farming in European Mediterranean wetlands performs a valuable non-marketable function related to the provision of environmental services. Rice and biodiversity are jointly produced, so that provision of flooded-rice-fields based environmental services depends crucially on private profitability of rice farming. Recent reforms of the Common Agricultural Policy (CAP) and increasing access of third party countries to the domestic European market are challenging the competitiveness of European rice growers. This paper combines conventional competitiveness indicators and non-parametric efficiency analysis to ascertain the economic profitability of rice cultivation in the Albufera Natural Park (Eastern Spain). Our main results are as follows. First, the current competitiveness of rice farming in this highly valued agro-ecosystem depends crucially on CAP support. Second, if rice growers were performing efficiently, short-run competitiveness could be achieved without CAP support. Third, the current scheme of environmental payments would be sufficient to bring about the long run competitiveness of efficient farmers, thus guaranteeing the survival of a wealth of biodiversity associated to the Albufera wetlands. Finally, we also find that outsourcing certain growing tasks to external service firms improves the chances of rice farms working efficiently.
\end{abstract}

Keywords: European Mediterranean wetlands, rice farming, agro-ecosystems, CAP support, competitiveness, profit-efficiency.

\section{INTRODUCTION}

The analysis of agricultural systems in developed countries is currently influenced by new visions concerning the role played by farming in a broad societal context. The traditional food-and-fibre production function is being downplayed, while there is an increasing concern with the role of farming in the stewardship of nature [1]. Also, the ability of agriculture to sustain a minimum of economic activity in less favoured areas, thus guaranteeing their economic viability, receives considerable attention within the context of rural development policies. Multifunctionality has been coined as a workable concept to deal with these multiple facets of modern farming [2].

In this framework, our paper reflects on the present features and future prospects of a highly valuable agroecological system, which is being endangered by a lack of economic viability: rice farming in European Mediterranean

*Address correspondence to this author at the Universidad de Valencia, Dpto, Economía Aplicada II, Avda dels Tarongers s/n, 46022 Valencia, Spain; Tel: +34 963828 349; Fax: +34 963828 354;

E-mail: Andres.j.picazo@uv.es

\footnotetext{
${ }^{1}$ Although this is the most commonly employed term to refer to the manifold facets of agriculture, other terms are also used, e.g. multifunctional landscape [3].
}

wetlands. Rice production in these areas supports a wealth of biodiversity, and displays other non-productive functions, but private profitability is undermined by cost disadvantages against international markets. Recent changes in rice's Common Market Organisation (CMO), and the trend towards a complete elimination of trade barriers vis-a-vis less developed countries, cast serious doubts on the future of these farming systems. Particularly, we focus our analysis on rice farming in the Albufera Natural Park, located in the region of Valencia (Eastern Spain), because it represents the sort of rice fields that were mentioned as a source of positive environmental externalities in the review of the Spanish literature on agricultural multifunctionality commissioned by the OECD [4].

Furthermore, the decision to target a local rice farming system instead of a wider regional or national cropping area, was based on the view that the concept of multifunctionality, and the associated case for public policy interventions, are rather weak as a basis for a nation-wide agricultural strategy. The reason is that joint production of commodity and noncommodity farm outputs becomes more and more elusive as one proceeds from local, well documented, crop-specific interactions, to more general farming sector analysis. Production jointness is the key for justifying public support measures to farmers aimed at avoiding the loss of valuable non-marketable functions, and only site-specific research can 
provide much needed scientific evidence to prove or reject its existence.

When public and private goods are jointly produced by agriculture, lack of economic viability leading to abandonment of marketable farm output production may discontinue the supply of non-market goods. This paper is primarily concerned with the use of short and long-term competitiveness indicators to assess the viability of rice farming in the Albufera Natural Park. However, our research goes a step further from conventional profitability analysis, introducing the perspective of what farmers could do in order to rise to the challenge posed by international competition and trade liberalisation. In doing so, we draw a clear distinction between observed and efficient farmer behaviour. While observed farmer behaviour translates into the measurement of current competitiveness, efficient behaviour makes it possible to measure competitiveness in a virtual scenario, where best profit-maximising practices have spread from the best performing farmers to the rest.

A comparison of the observed and efficient scenarios is full of important implications for both farmers and policymakers. On the one hand, it provides farmers with valuable information to determine whether an improvement in their managerial performance could simultaneously contribute to ameliorate their financial situation and guarantee the survival of valuable agri-environmental functions. On the other hand, it helps policy-makers ascertain whether or not efforts aimed at increasing efficiency could bridge the gap between the current lack of profitability in rice farming in the area and farms' financial viability in the future. In addition, this comparison might also contribute towards improving the design of public policies targeted at internalising the positive externalities generated by this agricultural system, e.g. even if farms, after profit-maximising adjustments have been adopted, remain dependant on public support, it is clear that the amount of support needed to maintain the nonmarketable function of rice farms would be lower than if no efficiency considerations had been included in the analysis.

Furthermore, we focus on purely economic efficiencyenhancing management changes because Albufera Natural Park's regulations and farmers' agri-environmental commitments under a local agri-environmental program, jointly funded by the $C A P$ of the European Union and regional authorities, take care of the prevention of negative environmental externalities. Chemical products implying a major risk for the ecosystem are currently prohibited. This has reduced most of the negative externalities previously generated, such as water pollution by phytosanitary products or nitrates, or the loss of algae and lacustrine vegetation through the use of herbicides. Also, in order to be eligible for agri-environmental payments, farmers must fulfil regulations which make it compulsory to flood rice fields in winter, restrict the amount of fertiliser used, treat Chilo suppressalis (a stem borer plague) with pheromones and to mechanically control weeds on the edges of fields and in irrigation channels, as well as in the fields themselves, before planting.

The rest of the paper proceeds as follows. Section 2 describes the main positive externalities from rice farming in the Albufera Natural Park. Section 3 deals with current CAP support to European rice growers and computes competitiveness indicators of rice farming in the Albufera
Natural Park. In section 4, profit efficiency and its determinants are analysed. Section 5 summarises and concludes.

\section{FLOODED RICE FIELDS AS A SOURCE OF POSITIVE EXTERNALITIES: THE $A$ LBUFERA}

There seems to be an emerging consensus regarding the types of environmental services that can be considered joint products of rice production [5]. Some of them are hydrological. Flood control is important in hilly areas, as paddy fields store waters and decrease the possibility of a sudden peak discharge of water flows severely flooding downstream areas. Moreover, the rural landscape provided by rice fields may be valuable for the local population and for urban dwellers eager to enjoy rural amenities. However, externalities of rice farming linked to biodiversity conservation deserve special attention, as they are of paramount importance in our case.

Rice fields have become habitats for wildlife species of amphibians, birds, crustaceans, fish, insects and molluscs. Flooded rice fields are particularly valued because they can act as partial substitutes for natural wetlands. Wetlands perform many valuable functions on different ecological scales and are the only single group of ecosystems to have their own international convention since 1971, the Ramsar Convention $^{2}$, primarily because of their outstanding importance as a habitat for migratory species [6]. Despite these widely recognised values, wetlands have become increasingly scarce all over the world, as they have been lost to urban and industrial development, or progressively drained of water for farming uses. The degradation or disposal of wetlands has frequently happened as a consequence of market failures due to the public nature of several of the goods supplied by these ecosystems.

The role of flooded rice fields in providing equivalent foraging habitat to semi natural wetlands has been stressed in the literature, pointing to the similarities in the behaviour of the bird species observed in both habitats [7]. Rice fields are particularly important in Southern Europe as a feeding habitat and breeding site for birds, because they act as seasonal aquatic ecosystems, given that they are flooded some weeks in spring and during summer, a season in which the Mediterranean wetland areas suffer droughts. In some areas, such as the Albufera in Spain, rice fields are also flooded during the winter for ecological reasons. As a consequence, they have developed into suitable habitats for ducks, waders and gulls, as has been the case of the Ebro Delta and the Albufera in Spain, and the Camargue in France [8]. Rice fields have been considered as important as feeding sites for herons and other water birds as the combined total of all other aquatic habitats in Southern Europe. For some species, like herons, the agricultural habitats supply between 50 and $100 \%$ of the birds' food during the peak breeding season [9]. Rice fields can thus be seen as strongholds for breeding herons in Southern Europe. Tucker and Evans [10] also cite a wide range of bird species that populate European rice fields.

\footnotetext{
2 The Ramsar Convention on Wetlands of International Importance Especially as Waterfowl Habitat is an intergovernmental treaty signed in the Iranian city of Ramsar for the conservation and wise use of wetlands.
} 
In Spain, rice cultivation is particularly important for biodiversity protection. It has been estimated that at least 25 bird species of European conservation concern regularly use rice fields during wintering or as stopover foraging habitats during migration and that 16 species use them during the breeding season [9]. As natural coastal wetlands have been reduced, by draining up for farming, real estate development and construction of infrastructures, rice fields can serve as partial replacements. The Spanish white book of agriculture and rural development [11] established that $60 \%$ of Spanish wetlands were lost or seriously damaged throughout the 20th century.

The Albufera Natural Park is located in the vicinity of the Metropolitan Area of the city of Valencia, with some 1.5 million inhabitants, protects 21,120 hectares of wetland complex, and was declared a Ramsar site in 1990. Its semiurban character enhances the value of this area as a natural resort of great recreational interest. The Albufera is a fresh water coastal lagoon with abundant emergent vegetation and pine tree woodland, fringed by rice fields that cover a surface of 14,350 hectares of land. Rice has been a traditional monoculture in this area, and the crop is irrigated by flooding.

Flooded rice fields around the Albufera lake provide the predominant regional feeding area for some bird species like ducks, common cranes and egrets, because the eutrophication of the waters of the Albufera prevents the lake itself from supplying enough food to cover birds' needs. Anatidae is the largest group of water birds that winters in the Albufera Natural Park, numbering between 40,000 and 60,000 individuals. One of the members of this family, the red-crested pochard (Netta Rufina), is of outstanding importance: its 17,000 individuals form the largest population of this species in Western Europe. Among the wintering Ardeidae, the best represented species are herons (Ardea Cinerea), cattle egrets, also known as buff-backed herons (Bubulcus Ibis), and little egrets (Egretta Garzetta).

The rice fields in the Albufera Natural Park are of vital importance for the food chain, providing for the feeding of most of the species inhabiting this area [12]. Dies et al. [13] have linked the winter breeding by black-crowned night herons (Nycticorax nycticorax) in the Albufera area to the extra food supplied by the rice fields in these months. Moreover, Dies et al. [14] described the diet of nesting gullbilled terns (Sterna nilotica) in Eastern Spain, finding that it depended almost exclusively on catches of red swamp crayfish (Procambarus clarkii) that inhabit the rice fields. Thus, an interruption in rice production would seriously affect this ecosystem, with around $70 \%$ of the flooded area of the Albufera Natural Park being lost and wild fauna severely depleted. Bird species populations would suffer from rice field abandonment because it has been estimated that no less than 5,800 tons of rice production remain on the ground in the post-harvest season to be used by birds. It is likely that the concomitant negative changes in wild fauna arising from a disruption in rice production would damage the status of the Albufera as an internationally renowned Ramsar site. Furthermore, no other crops can substitute for rice in this area, because most of the soils are saline and do not admit non-flooded cultivation systems [15].
Biodiversity protection is not the only non-commodity output produced by this multifunctional agricultural system. It is also worth mentioning the function of purification by decantation of the urban residual waters that are emptied into the lake. Rice fields also perform an important public health function, by preventing a marsh land area developing into a source for transmitting diseases [16]. The rice fields and the Albufera Natural Park also constitute a highly regarded traditional landscape, which has been preserved by virtue of the restrictions on land use imposed by the Park's legislation.

Considerable efforts have been made in the literature to assess the non-market values of some of the multiple outputs provided by paddy rice production ${ }^{3}$. Boisvert and Blandford [18] have stressed the need to correct for market failure by valuing non-commodity outputs correctly, changing current policies that do not provide the desired support for multifunctional goods and addressing concomitant redistribution issues separately.

In a recent work based on the use of multi-criteria methods, Navarro [19] has estimated a social value for the Albufera Natural Park of 3,484 million $€$, of which 2,270 million $€$ correspond to its non-use value, which includes its value of existence as an ecosystem of paramount importance to maintain the biodiversity in the area. This value of existence is estimated to be around 65.8 thousand $€$ per hectare. Furthermore, Suárez-Burguet et al. [20] assessed the recreational use value of the Albufera Natural Park using contingent valuation methods, obtaining a willingness to pay that, when converted into 2007 prices, amounts to $6.87 €$ per visitor. Considering that the annual number of visitors ranges from 1 to 1.2 million, the recreational value of the Albufera Natural Park could be estimated at between 6.8 and 8.2 million $€$.

\section{PROFITABILITY OF RICE FARMING IN THE ALBUFERA}

From the arguments presented in the previous section, it immediately follows that a severe profitability crisis in rice farming in the Albufera Natural Park leading to abandonment of rice growing, would critically affect the other functions performed by this agricultural system, i.e. ecological, sanitary or landscape functions. Hence, this section seeks to analyse the short and long-term competitiveness of rice farming in this area.

Rice farming profitability is assessed using data from a comprehensive survey undertaken by the authors. The data correspond to the year 2004. Polls were conducted on 141 farms exclusively dedicated to rice growing in the neighbourhood of the Albufera lake, with nearly one hundred questions aimed at characterising the productive process, and describing farmers' socioeconomic characteristics. In addition, the survey included a wide-ranging set of questions relating to farmers' qualitative perceptions, some of them closely related to the environmental role played by this agricultural system. Lack of response on some relevant

\footnotetext{
${ }^{3}$ Fuwa and Sajise [5] review the empirical literature about the measurement of environmental externalities of rice fields. A recent paper on this issue is that by Tseng and Chen [17].
} 
variables and deletion of potential outliers reduced our final sample to 131 rice farms.

Profitability of rice farming in the Albufera area depends on sales revenue, heavily influenced by the gradual closing of the gap between domestic and international prices, and on a system of institutional support that the $C A P$ confers on rice growers. Rice farmers operating within the Albufera Natural Park are currently provided with two different types of CAP support, according to European Union legislation. The first one corresponds to agri-environmental payments, and is intended to protect the important environmental functions performed by rice farming in this area. These payments amount to $398 €$ per hectare (Regulation CE 1698/2005). The second support mechanism is embedded in the system of specific market interventions and trade protection that the CAP uses to uphold farmers' income, consisting of commercial protection and export subsidies, public intervention purchases, and direct aid per hectare. However, recent changes in these mechanisms have added to the uncertainty concerning the future prospects of rice farming in the Albufera Natural Park, putting additional strain on farmers.

On the one hand, the Uruguay Round Agricultural Agreement established restrictions on the use of export subsidies paving the way for a future of free access of imports to European domestic markets. Furthermore, the Everything But Arms Initiative, adopted by the European Union in favour of less developed countries (Regulation EC, 416/2001), will grant free access for rice to the internal European market in September 2009. On the other hand, after the 2003 reform of the CAP, the intervention price for paddy rice was cut by $50 \%$, with the purpose of reducing the gap between international and domestic European prices. By way of compensation, farmers are now entitled to benefit from a single payment or decoupled subsidy that amounts to $647.70 €$ per hectare. Additionally, a cropspecific coupled payment of $476.25 €$ per hectare of land sown under rice is also granted.

Let us now move to the assessment of private profitability of rice growing in the Albufera under the post-2003 reformed CAP support scheme. Economic returns to family labour have to be compared with the alternative returns available off-farm. The opportunity cost for family labour can be ascertained from market wage rates in the farm labour market or in other economic activities, when, as in the case of the Albufera rice system, farmers or their relatives have opportunities to take local service, manufacturing or building industry jobs. A basic distinction needs to be drawn, however, between short-term competitiveness, when assets that are farmer's property should be considered as sunk costs, and long-term competitiveness. In the long-term an opportunity cost has to be attributed to all farm assets, including land and capital owned by the farm household.

Indicators of both short- and long-term competitiveness are computed according to the definitions provided in Monke et al. $[21, \mathrm{pp} .8-10]^{4}$. Our short-run indicator evaluates the ability of farms to remain temporarily in operation even if farming revenue does not allow the recovery of the full opportunity cost of all family-owned farm assets. It measures the ratio between farm revenues, net of intermediate input costs and payments for hired labour and rented land or machinery, and the input of family

\footnotetext{
${ }^{4}$ A European project devoted to analyse the $C A P$ and the development of
} Mediterranean agriculture also uses this sort of indicators [22]. labour to the farm, which is measured in Annual Working Units $(A W U s)$. The remuneration imputed to a unit of family labour is thus inclusive of the returns earned by capital and land owned by the family. But in the long-term a farming system should provide all employed resources a rate of return close to the return obtained in their best alternative use. It means that capital and land owned by the agricultural household have to be fully costed. Accordingly, our long-run competitiveness indicator is computed as the quotient between farm revenues, when the cost of all inputs, except family labour, has been subtracted ${ }^{5}$, and the input of family labour to the farm.

Competitiveness has been assessed at the farm level under two different scenarios concerning the sources of farmers' income. In the first one, farmers' income is computed by adding up the revenue from output sales at market prices, agrienvironmental payments, and the post-2003 $C M O$ subsidies. Only coupled subsidies have been considered, as the decoupled ones are not rice-specific. The second scenario represents a hypothetical situation where rice farmers are deprived of $C A P$ support, so that revenue from output sales constitutes their only source of income. Indicators of competitiveness expressed per $A W U$ of on-farm family labour are presented in Table $\mathbf{1}$, which also shows net returns per farm. The most outstanding result is that rice farming could not survive in the long-term if deprived of $C A P$ support. Even in the short-term, net economic returns to farmer's labour are very modest if agri-environmental and $C M O$ subsidies are not taken into account.

Let us now compare the long-term returns obtained by an $A W U$ of on-farm family labour, inclusive of $C A P$ financial support, with the incomes available off the farm. Given that only $8 \%$ of off-farm family labour in our sample is employed in the farming sector, the comparison should be established with earnings from non-agricultural occupations. Current local economic conditions suggest that a reasonable benchmark corresponds to the average wage income in the building industry. According to the estimations provided by the Spanish Instituto Nacional de Estadistica, in the region of Valencia the average labourer in the building industry earned some $14,788 €$ on an annual basis in 2004. This figure is significantly higher than the $11,182 €$ earned in rice farming, as showed by our long-run competitiveness indicator.

The literature in the field of agricultural economics has pointed out that farmers may willingly work for an implicit wage lower than the alternative wage that its labour force could command in the labour market [23, 24]. This preference is fully rational if some special amenities of on-farm labour compared to off-farm waged jobs are considered. The autonomy granted by owning the farm, the quality of rural life, and the higher cost of life in urban areas, could make up for the difference in earnings between farming and alternative off-farm jobs.

But looking only at average long-term income per $A W U$ might be misleading. The average daily earnings from farming of a family labour unit could be on a par with its opportunity costs and yet not guarantee the farm's viability. This would be the case if the total return to labour is too

\footnotetext{
5 Services of own capital have been priced using the cost of hired machinery, as a conventional opportunity cost. In addition, the private rent of land has been established according to the most common quotations for transactions in the local farmland rent market, currently around $721 €$ per hectare.
} 
small to absorb the household labour force, or even to guarantee a full time job for the farmer. In the Albufera Natural Park, no farmer possessing a rice farm of the average size would be able to survive, after correctly pricing its productive assets, on the sole basis of the remuneration of farm labour income. This is because the aggregate use of labour on the farm is equivalent to merely $0.2 A W U_{s}$. The assessment of competitiveness when net returns are computed per farm, shows that, even allowing for $C A P$ support, the revenue derived from farming falls clearly short of the minimum judged necessary to earn a living (see again Table 1).

Summing up, current economic viability of rice farming in the Albufera Natural Park, and thus the essential environmental functions developed by this highly valued farming system depend crucially on the continuation of $C A P$ support. Actually, support to rice farming in the Albufera Natural Park has been mentioned in the literature as one of the most successful agri-environmental schemes applied during the nineties in the European Union when it comes to supporting farm transformations that produce both private benefits for farmers and public ones for the environment [25]. Nonetheless, even in the event of current support being maintained, rice farmers will have to adjust in the coming years to a less protective environment, with increasing access of third countries' exporters to the internal European market. Lack of competitiveness requires rice farmers to follow a strategy of adjustment that pays due consideration to all available alternatives.

Several managerial strategies are already being observed. Some farmers follow a strategy of achieving a greater scale of operations, either buying or renting land, or making more efficient use of their machinery by performing some mechanised tasks for other farmers. Other rice growers are pursuing a very different path of adjustment, taking part-time off-farm jobs and outsourcing many of the productive tasks to service firms or cooperatives. Obviously, a wide range of intermediate situations also exists. Anyhow, the new scenario for European rice farmers demands an exploration of the different ways of overcoming the aforementioned lack of competitiveness. We next focus on one of these ways: managerial changes conducive to achieving better profit-efficiency levels.

\section{HOW FAR ARE RICE FARMS IN THE ALBUFERA FROM PROFIT-EFFICIENCY?}

In this section we explore the possibility of improving farms' management as a feasible way out from the lack of competitiveness of rice farming in the Albufera Natural Park. By doing so, we hope to reach a better understanding of the conditions that would improve the chances of keeping in place this multifunctional farming system. Assuming that managerial decisions of rice growers are intended to maximise profits, our aim here is to compare the observed behaviour of each rice farm in the sample with the best observed practices, in terms of a performance index. With this purpose, we make use of mathematical programming and Data Envelopment Analysis (DEA), introduced by Charnes et al. [26]. Reig-Martínez and Picazo-Tadeo [27] highlight the usefulness of these techniques for analysing farming systems. Further details on $D E A$ are in Cooper et al. [28].

It has been occasionally argued that some farmers would not actually follow a profit maximising strategy, but rather a strategy aimed at maximising a utility function that does not necessarily match the profit function [29]. In order to test for this possibility, rice growers interviewed in our survey were asked to manifest their degree of agreement with the following assertion: 'the most important target for a farm is to maximise profit'. Possible responses were ranked from 1 (total agreement) to 5 (total disagreement). Based on this scale of responses, nearly $80 \%$ of the farmers declared their agreement or total agreement with this statement. Thus, we can assume that rice growers in the Albufera follow a profit maximising strategy, and then evaluate their relative performance.

Prior to assessing performance, the rice farming productive process needs to be characterised, and some criteria used to price inputs need to be made explicit. In doing so, one output and eight production factors are considered. Output is measured in kilograms of rice production. The only fixed input is cultivated land (hectares), while variable production factors are: farm-owned and outsourced labour (measured in $A W U s$ ), farm-owned and outsourced capital (expenditure in $€$ ), fertilisers, seeds, herbicides and fungicides (all measured in $€$ ).

Table 1. Indicators of Current Competitiveness of Rice Farming in the Albufera Natural Park (Averages in $€$ )

\begin{tabular}{|l|r|r|}
\hline & Short-Run Competitiveness & Long-Run Competitiveness \\
\hline \hline Return per AWU of on-farm family labour & & \\
Including CAP support & 32,953 & \\
Agri-environmental payments and coupled subsidies & 20,857 & 11,182 \\
Agri-environmental payments only & 10,744 & -914 \\
Excluding CAP support & $-11,028$ \\
\hline Return per farm & & \\
Including CAP support & 6,138 & \\
Agri-environmental payments and coupled subsidies & 4,142 \\
Agri-environmental payments only & 2,474 \\
Excluding CAP support & -102 \\
\hline
\end{tabular}


Concerning prices, the price of rice has been set at $0.24 €$ per kilogram, and it is assumed to be the same for all farms in the sample. This assumption is based on the fact that all farmers produce similar varieties of rice, which are sold in the local market with no price differences. Family-owned labour has been priced using the cost of outsourced labour, as a conventional opportunity cost. The expenditure on farm-owned capital services has been computed, as previously noted, in terms of opportunity cost, considering total hours of use of own machinery and the price of outsourced capital services. It is assumed that all farms share the same price for labour and capital, because the markets for both production factors are local markets with no observed difference of prices. Finally, the price of inputs which are measured in monetary units has been conventionally set to one. Table 2 provides some descriptive statistics.

Regarding the nature of inputs, here we depart from conventional literature that considers all farm-owned production factors as fixed, including land, labour and capital. Considering within-farm labour and capital as variable production factors allows us to capture an important structural characteristic of agriculture in the area analysed: the importance of part-time farming and outsourcing as determinants of production management [30]. The highly diversified economic structure of the neighbourhood where rice fields are located, close to the city of Valencia and its metropolitan area, largely favours part-time farming, allowing farmers to earn wage income from employment in the local agricultural labour market or, increasingly, in services or industry. In addition, many mechanised tasks in rice farming are outsourced in the broad sense that they are not performed by the farmer or his family, but by small local service firms or co-operatives. As a result, both part-timing and outsourcing allow decisions on optimal allocation of farm-owned labour and capital to enter into farmers' short-run managerial strategy on the adjustment of production factors.

Moving on to the assessment of profit efficiency, computation of the productive plan which maximises short-run profit for each of the $i=1, \ldots, 131$ rice growers in our sample, requires the comparison of their actual observed data on output and inputs, with those of farms showing best observed practices.
Formalising, the productive plan that maximises short-run profit of farm $i$ ' arises from:

$\operatorname{Profit}\left(r, p, x_{f}^{i^{i}}\right)=\operatorname{Max}_{x_{v^{\prime}, y^{\prime}, z^{i}}}\left(r y^{y^{\prime \prime}}-\sum_{v=1}^{8} p_{v} x_{v}^{i^{i}}\right)$

subject to:

$$
\begin{array}{ll}
y^{i^{i}} \leq \sum_{i=1}^{131} z^{i} y^{i} & \\
x_{f}^{i^{i}}=\sum_{i=1}^{131} z^{i} x_{f}^{i} & f=1 \\
x_{v}^{i^{i}} \geq \sum_{i=1}^{131} z^{i} x_{v}^{i} & v=1, \ldots, 8 \\
z^{i} \geq 0 & i=1, \ldots, 131 \\
\sum_{i=1}^{131} z^{i}=1 &
\end{array}
$$

$y^{i}, x_{v}^{i}$ and $x_{f}^{i}$ being, respectively, the observed output and both variable and fixed inputs on farm $i$. Output price and prices of variable inputs are denoted by $r$ and $p_{v}$, in that order, while $z^{i}$ represents the weighting of each farm $i$ in the composition of the efficient frontier. Furthermore, the set of restrictions characterises a technology with variable returns to scale [31], satisfying the standard axioms proposed by Shephard [32].

Profit-maximising productive plans have been used to explore the financial consequences of eliminating managerial inefficiencies for the farms in our sample. Table $\mathbf{3}$ displays the values for the conventional indicators of competitiveness presented in Section 2, computed using profit-maximising data. Prior to commenting on these results, let us point out that the pursuit of a strategy of profit-maximisation leads to an increase of net returns per farm, but also to a reduction in the use of onfarm family labour, given that own labour has been considered a variable production factor. Therefore, the increase in competitiveness due to achieving profit-efficiency needs to be interpreted as the result of two forces acting in the same direction at the farm level: an increase in net returns, and a cut in the use of family labour.

The improvement in the economic returns per $A W U$ of onfarm family labour, once profit-inefficiencies have been eliminated, is quite impressive. Now, the amount of farm income that rewards a family's productive assets far exceeds the

\begin{tabular}{|c|c|c|c|c|c|}
\hline \multirow{2}{*}{ Variable } & \multirow{2}{*}{ Description } & \multirow{2}{*}{ Units } & \multicolumn{2}{|c|}{ Quantities } & \multirow{2}{*}{ Price ( $€$ Per Unit) } \\
\hline & & & Mean & Standard Deviation & \\
\hline Output & Rice & Kilograms & 34,712 & 62,208 & 0.24 \\
\hline Fixed input & Cultivated land & Hectares & 4.2 & 7.6 & - \\
\hline \multirow{8}{*}{ Variable inputs } & Own labour & AWUs & 0.16 & 0.23 & 12,052 \\
\hline & Outsourced labour & AWUs & 0.04 & 0.08 & 12,052 \\
\hline & Own capital & $€$ & 1,223 & 4,163 & 1 \\
\hline & Outsourced capital & $€$ & 1,747 & 3,181 & 1 \\
\hline & Fertilisers & $€$ & 477 & 905 & 1 \\
\hline & Seeds & $€$ & 584 & 1,074 & 1 \\
\hline & Herbicides & $€$ & 686 & 1,333 & 1 \\
\hline & Fungicides & $€$ & 276 & 603 & 1 \\
\hline
\end{tabular}
annual income of the average labourer in manufacturing, even in the absence of agri-environmental and $C M O$ subsidies. Farmers are thus able to achieve short-run competitiveness.

Table 2. Characterisation of Rice Farming Production Process (Averages Per Farm) 
Table 3. Indicators of Competitiveness of Rice Farming in the Albufera Natural Park Computed Using Profit-Maximising Data (Averages in $€$ )

\begin{tabular}{|l|r|r|}
\hline & Short-Run Competitiveness & Long-Run Competitiveness \\
\hline \hline Return per $A W U$ of on-farm family labour & & \\
Including $C A P$ support & 94,288 & \\
Agri-environmental payments and coupled subsidies & 65,624 & 48,500 \\
Agri-environmental payments only & 41,658 & 19,837 \\
Excluding $C A P$ support & $-4,129$ \\
\hline Return per farm & & \\
Including $C A P$ support & & \\
Agri-environmental payments and coupled subsidies & 3,008 \\
Agri-environmental payments only & 5,013 & \\
Excluding $C A P$ support & 3,345 & \\
\hline
\end{tabular}

Long-run competitiveness also improves dramatically, but in this case the ability of farms to survive still depends on the continuity of policy support. Agricultural households would still be in the red if all productive assets were fully costed, according to their opportunity costs, and $C A P$ subsidies were not flowing in. The difference with regard to the profit-inefficient situation is that now losses are being cut to 4,129 € per $A W U$ of on-farm labour.

More interestingly, our indicators of competitiveness computed using profit-maximising figures reveal that if rice farmers in the Albufera Natural Park were managing their farms efficiently, agri-environmental payments would assure by themselves, i.e. without the additional support from coupled subsidies, the long-run viability of this agricultural system. In this situation, the scheme of agri-environmental payments, intended to protect the environmental function performed by rice farming in the Albufera area, would guarantee an annual net income of $19,837 €$ per $A W U$ of on-farm labour, a figure moderately higher than earnings in alternative activities. Even in the foreseeable scenario of a reduction of the price of rice in the domestic European market due to stronger competition, the current scheme of agri-environmental payments granted to rice farmers could be sufficient to maintain the economic viability of rice farming in the Albufera Natural Park, thus guaranteeing the essential role of this multifunctional agricultural system in providing environmental services of paramount importance.

In other words, our analysis clearly shows that enhancing management performance will substantially improve the likelihood of survival of rice farming in the Albufera, thus contributing towards the maintenance of a variety of positive environmental externalities stemming from rice cultivation, e.g. feeding and nesting birds of threatened species. In this particular case, local public good features produced by this agricultural system cannot be de-linked from private output supply decisions on behalf of farmers, which in turn are influenced by efficiencyimproving and profit-maximising management changes.

Even if management changes, leading to an improvement in rice farming efficiency, are successfully implemented, important challenges loom ahead that threaten to disrupt the provision of environmental services. It has been widely recognized that water resources in meridional European regions are currently under great pressure, and the situation is not expected to ease for the next few decades [33]. Spanish Mediterranean semi-natural wetlands are suffering from recurrent droughts that are further aggravated by competing demands for water on behalf of irrigation agriculture and tourist and urban development. Rapid urban development is a matter of particular concern, as the European Corine Land Cover Project has shown that between 1986 and 2000, artificial land cover (urban development and industrial sites or infrastructures, among others) increased by $47 \%$ in the region of Valencia [34]. The ensuing Spanish real estate boom of the last few years has undoubtedly accelerated this trend. But climate change will exert a more lasting influence. In fact climate change is the main factor currently affecting the availability of water in this area of Europe [35], also resulting in a negative impact on water quality and aquatic ecosystems [36]. The Albufera Natural Park suffers from two primary vulnerabilities to climate change, being a coastal area and being located in Southern Europe. Increasing water scarcity and a change in the timing of water availability could, therefore, have a marked impact on this highly-valued agricultural system, jeopardizing the environmental functions of rice farming.

The assessment of competitiveness in terms of net returns per farm also reveals a substantial amelioration of profitability, but in this case the improvement is not as significant. The reason is that the average farm is too small to afford farmers a fulltime job. The modest absolute levels of economic returns per farm, even after economic inefficiencies have been eliminated, points to a fundamental structural weakness of rice farming in this area, related to the small size of most farms. Accordingly, farm concentration should be pursued as a policy target in the long run, besides the emphasis on an improvement of short-run farm efficiency levels.

With the intention of going further into the study of managerial efficiency, we have carried out a second-stage analysis aimed at investigating the factors related to farms' performance. Previously, a profit-efficiency indicator has been worked out at farm level, by comparing current observable profits with those that could be achieved after a profit-maximising adjustment of both variable inputs and output. According to Färe et al. [37, p. 214], this index of overall efficiency arises from the following relationship: 
$\operatorname{Profit}\left(r, p, x_{f}\right)=\frac{r y}{O_{g}(x, y, p, r)}-O_{g}(x, y, p, r) p x_{v}$

where $O_{g}(x, y, p, r)$ is the so-called graph measure of profitefficiency, and Profit $\left(r, p, x_{f}\right)$ is the short-run profit computed as the solution to program $(1)^{6}$.

In addition, Simar and Wilson's simple algorithm [38] is employed to explain farms' managerial inefficiency ${ }^{7}$, defined as the inverse of the profit-efficiency scores obtained in our $D E A$-based first stage. Details on this algorithm are in the Appendix. Regarding the features capable of influencing performance, we include traditional variables such as farmers' educational level, age and farm size, in addition to a variable that captures a specific characteristic of rice farming in the Albufera: the degree of outsourcing ${ }^{8}$. Education is proxied by the average years of schooling, and size is measured in hectares. Furthermore, outsourcing is proxied by the cost of outsourced labour and capital services as a proportion of the total cost of these production factors. Table 4 displays the estimated parameters, and their confidence intervals.

Table 4. Determinants of Profit-Inefficiency (Confidence Intervals at $95 \%)^{(1)}$

\begin{tabular}{|c|c|c|c|}
\hline & Estimated Parameter & Lower Bound & Upper Bound \\
\hline \hline Constant & 1.28017 & 1.08972 & 1.48644 \\
\hline Age & 0.00128 & -0.00177 & 0.00378 \\
\hline Education & -0.00026 & -0.00898 & 0.00826 \\
\hline Size & -0.00864 & -0.01536 & 0.00132 \\
\hline Outsourcing & -0.23277 & -0.43375 & -0.01910 \\
\hline Sigma & 0.16627 & 0.13529 & 0.19982 \\
\hline
\end{tabular}

(1) The number of replications in the bootstrapping has been set at 1000 .

Empirical evidence reveals, with a 95\% confidence level, that outsourcing positively and significantly affects rice farmers' managerial performance, so that the bigger the weighting of outsourced labour and capital on farms' total use of these inputs, the smaller their profit-inefficiency. This result is in line with previous literature, which has pointed to the importance of outsourcing as a managerial strategy aimed at increasing competitiveness in farming systems with a predominance of small farms, and where farmers can profit from local flexible labour markets [40]. Besides, outsourcing is a strategy increasingly adopted by Spanish farmers, especially for performing those tasks that require the use of machinery [41]. This is precisely the case of rice farming in the Albufera Natural Park, where capital services are actually the main component of the set of outsourced inputs.

In general, capital services are outsourced to other rice farmers in the area who, as mentioned in Section 2, have

\footnotetext{
6 The mean of the individual scores of profit-efficiency is 0.826 . Furthermore, revenue should be increased, on average, by $13 \%$ and costs cut by $22 \%$ in order to attain profit-efficiency.

${ }^{7}$ Balcombe et al. [39] use a similar methodology to explain efficiency in Bangladesh rice farming.

${ }^{8}$ Other variables for which we have no data, such as credit accessibility, experience or vocational training in agriculture, could also affect the performance of rice growers.
}

decided to follow a managerial strategy aimed at attaining a greater scale of operations by using their own machinery to perform mechanised tasks for other rice farmers. Sometimes, these labourers adopt the legal form of small service firms, or they work for co-operatives performing services for their members. The key matter here is the greater efficiency displayed by those professional labourers or service firms that are actually performing mechanised tasks on behalf of rice farmers in the Albufera Natural Park.

Apart from outsourcing, none of the other variables considered seems to have a statistically significant relationship with managerial performance. This comes as a surprise, since one would expect farms managed by younger farmers or farmers with a higher educational level to show higher profitefficiency levels. Nonetheless, our view here is somewhat different. Due to the wide-spread strategy of outsourcing labour and capital, what really matters to explain farms' managerial efficiency is the skilfulness of the external labourers or service firms performing outsourced tasks, and not so much the particular ability of the farmer, proxied by variables like education or age. As noted, these service firms enjoy some kind of competitive advantage, because they can more easily acquire specialisation skills and expertise in operating with machines that incorporate new technologies [42].

This research has the ultimate purpose of helping to bring economic analysis closer to the concerns of policy-makers. In our view, our results affect a couple of issues of interest for agricultural policies. On the one hand, policy measures targeted at spreading best practices among rice farmers in the Albufera Natural Park might be of some help in improving rice farmers' competitiveness, thus contributing to sustaining this multifunctional farming system. On the other hand, these policies should pay particular attention to the upgrading of organisational skills and access to the latest technologies on the part of those service firms and co-operatives that contribute substantial capital and labour inputs to different tasks in rice farming.

\section{SUMMARY AND CONCLUDING REMARKS}

Rice farming in European Mediterranean wetlands performs, beyond its traditional food supply function, the essential role of providing environmental services and protecting biodiversity and landscape. The need to open the internal European market to third countries' exporters in addition to recent changes in the mechanisms used by the $C A P$ to uphold rice farmers' income, are imposing serious uncertainties on future profitability prospects for European rice growers, thus jeopardising the wealth of biodiversity produced by these highly valuable ecosystems. Rice farming in European Mediterranean wetlands could be a case where the removal of distortions generated by the $C A P$ could actually have a negative impact on society's welfare. Or, in other words, by eliminating some distortions, the European Union might be in the process of creating new ones.

In this paper, we focus on rice farming in the Albufera Natural Park, located in the East of Spain. Based on information from a survey conducted specifically for this study, we have assessed farms' short and long-term competitiveness. Results are conclusive: current rice farming profitability dramatically depends on the continuation of CAP support. Nonetheless, even if the current support is maintained, rice growers will need to adjust in the coming years to a more 
competitive environment, because of the increasing access of third countries to the internal European market, and a progressive closing of the gap between domestic and international rice prices. Accordingly both farmers and policymakers should explore fresh ways to overcome lack of competitiveness. In this paper, we particularly focus on changes conducive to achieving better management.

Our findings show that rice farms in the Albufera Natural Park could increase competitiveness by improving their profitefficiency levels. Better managed rice farms would be able to survive in the short-term even if they were deprived of $C A P$ support, helping to preserve their environmental role. Improving management would also help to raise competitiveness in the long term, although in this case the economic viability of farms would still depend on the continuity of policy support. However, an interesting result of this research is that if rice farmers were managing their farms efficiently, the current scheme of agrienvironmental payments, intended to protect the environmental functions of rice farming in the Albufera Natural Park, would probably be sufficient to guarantee the future viability of this agricultural system, even if the price of rice fell moderately as a consequence of an increase in international competition.

Furthermore, our results indicate that outsourcing certain tasks to external service firms improves the chances of rice farms attaining profit-efficiency. Enhancing managerial performance is not the only consequence of outsourcing, as it also facilitates the adoption of a time-saving strategy on the part of those part-time farmers that absolutely predominate in this area. The small size of the farms and the economic conditions prevailing in this periurban agriculture strongly favour this strategy, which possibly could not be satisfactorily put to use in other places.

From a methodological standpoint, our work shows the usefulness of combining conventional competitiveness indicators and $D E A$-based efficiency analysis to achieve a more accurate understanding of the competitiveness prospects of an agricultural system. From an economic policy standpoint, we consider that our findings lead to noteworthy implications for policy-makers. Agricultural policies aimed at spreading technological innovation and best managerial practices might contribute to improving rice farms' competitiveness. Moreover, in this particular case, these policy measures should mainly target the service firms and external labourers that are currently involved in performing some outsourced tasks in rice farming. Finally, a strategy of farm amalgamation aimed at attaining a greater scale of operation also emerges as a policy target to be pursued, besides the emphasis on an improvement of short-run farm efficiency levels. But this last point is beyond of the scope of this paper.

\section{ACKNOWLEDGEMENTS}

The authors acknowledge the comments from two referees. This research has benefited from the financial support from Spanish Ministerio de Educación y Ciencia and the FEDER (project AGL2006-05587-C04-03/AGR). Andrés J. PicazoTadeo also acknowledges the financial support from Spanish Ministerio de Ciencia e Innovación and FEDER under project ECO2008-05908-C02-02. The usual disclaimer applies.

\section{APPENDIX}

Performing the simple algorithm proposed by Simar and Wilson [38, pp. 141-143] to explain managerial inefficiency of rice farmers requires to follow the next three steps:

Step 1.- Use maximum likelihood to obtain estimates $\hat{\beta}$ and $\hat{\sigma}_{\varepsilon}$ of $\boldsymbol{\beta}$, and $\sigma_{\varepsilon}$, respectively, in the truncated regression of the inefficiency scores estimated in the $D E A$-based first stage ( INEF ) on a set of covariates $z_{i}$, using the subset of $i=1, \ldots, \mathrm{m}<131$ inefficient observations, i.e. observations with a score of profit inefficiency greater than one. Formally:

$$
I N E F_{i}=z_{i} \beta+\varepsilon_{i}
$$

Step 2.- Loop over steps (2.1) to (2.3) $L$ times to obtain a set of bootstrap estimates of $\boldsymbol{\beta}$ and $\sigma_{\varepsilon}$ :

Step 2.1 For each $i=1, \ldots, \mathrm{m}$, draw $\varepsilon_{i}$ from the following normal distribution:

$$
N\left(0, \hat{\sigma}_{\varepsilon}^{2}\right) \text { left truncated at point }\left(1-z_{i} \hat{\boldsymbol{\beta}}\right)
$$

Step 2.2 Yet again, for each $i=1, \ldots, \mathrm{m}$, compute:

$$
\left(I N E F_{i}\right)^{*}=z_{i} \hat{\boldsymbol{\beta}}+\varepsilon_{i}
$$

Step 2.3 Use maximum likelihood method to estimate the following truncated regression:

$$
\left(I N E F_{i}\right)^{*}=z_{i} \boldsymbol{\beta}+\varepsilon_{i}
$$

Jointly, steps (2.1) to (2.3) yield a set of bootstrap estimates of $\boldsymbol{\beta}$ and $\sigma_{\varepsilon}$ :

$$
\wp=\left\{\left(\hat{\boldsymbol{\beta}}^{*}, \hat{\sigma}_{\varepsilon}^{*}\right)_{b}\right\}_{b=1}^{L}
$$

Step 3.- Finally, use values in $\wp$ and the original estimates of $\beta$ and $\sigma_{\varepsilon}$ to construct estimated confidence intervals for $\beta$ and $\sigma_{\varepsilon}$. 


\section{REFERENCES}

[1] Swinton S, Lupi F, Robertson G, Hamilton S. Ecosystem services and agriculture: cultivating agricultural ecosystems for diverse benefits. Ecol Econ 2007; 64: 245-52.

[2] OECD. Multifunctionality: towards an analytical framework. USA: OECD Publishing 2001.

[3] Mander U, Wiggering H, Helming K, Eds. Multifunctional land use. Berlin Heidelberg: Springer-Verlag 2007.

[4] Tió C, Atance I. Multifunctionality: applying the OECD framework. A review of literature in Spain: OECD Workshop on Multifunctionality, 2-3 July, Paris 2001.

[5] Fuwa N, Sajise AJ. Towards environmental services incentive policies for the rice sector: a survey and a Philippine case study. Roles of Agriculture Project. Agricultural and Development Economics Division. Food and Policy Organization of the United Nations 2006.

[6] Turner RK, van den Bergh JC, Söderquist TY, et al. Ecologicaleconomic analysis of wetlands: scientific integration for management and policy. Ecol Econ 2000; 35: 7-23.

[7] Elphick CS. Functional equivalency between rice fields and seminatural wetland habitats. Conserv Biol 2000; 14: 181-91.

[8] Fasola M, Ruiz X. The value of rice fields as substitutes for natural wetlands for waterbirds in the Mediterranean region. Col Waterbird 1996; 19: 122-8.

[9] Fasola M, Ruiz X. Rice farming and waterbirds: integrated management in an artificial landscape. In: Pain DJ, Pienkowski MW, Eds. Farming and birds in Europe: the Common Agricultural Policy and its implications for bird conservation. New York: Academic Press 1997.

[10] Tucker GM, Evans MI. Habitats for birds in Europe: A conservation strategy for the wider environment. Cambridge: Birdlife International 1997.

[11] Ministerio de Agricultura, Pesca y Alimentación (MAPA). Libro blanco de la agricultura y el desarrollo rural. Madrid: Secretaría General Técnica 2003.

[12] Martínez-Abrain A. Patrones de asociación de anátidas durante la invernada en un dormidero del este español. Ardeola 1999; 46: 163-9.

[13] Dies JI, Ramón N, Prosper J. Winter breeding by black-crowned night heron in Eastern Spain. Waterbirds 2003; 26: 379-82.

[14] Dies JI, Marín J, Pérez C. Diet of nesting gull-billed terns in Eastern Spain. Waterbirds 2005; 28: 106-9.

[15] SEO. Mejora de la gestión del hábitat en la ZEPA del delta del Ebro. Spain: Sociedad Española de Ornitología 2001.

[16] Estruch V, San Bautista A, López S, Maroto JV. El cultivo del arroz en la Comunidad Valenciana: algunas ideas para evitar la crisis que se avecina. Spain: Agrícola Vergel 2003: pp. 60-8.

[17] Tseng W, Chen CH. Estimating the wetland rental fee: a case study involving a Taiwan wetland. Appl Econ 2008: IFirst: 1-10.

[18] Boisvert RN, Blandford D. Multifunctionality and non-trade concerns: implications for future agricultural policy in Asia. Paddy Water Environ 2006; 4: 223-8.

[19] Navarro JV. Valoración de activos medioambientales utilizando técnicas multicriterio: caso Parque Natural de la Albufera (Valencia). Degree Dissertation. Spain: Universidad Politécnica de Valencia 2007.

[20] Suárez-Burguet C, del Saz-Salazar S, Pérez y Pérez L. Environmental management of protected areas in Spain: the recreational use value of L'Albufera Natural Park. In: Usó JL, Brebbia CA, Power H, Eds. Ecosystems and sustainable development. Advances in ecological Sciences. Comput Mech Publ 1998: pp. 305-16.
[21] Monke E, Avillez F, Pearson S. Small farm agriculture in Southern Europe: CAP reform and structural change. Vermont: Ashgate Publishing 1998

[22] Avillez F, Ed. The CAP reform and the development of Mediterranean agriculture. Final Report, European Research Project FAIR 3, CT 96-1579 2000.

[23] López RE. Structural models of the farm household that allow for interdependent utility and profit-maximization decisions. In: Singh I, Squire L, Strauss J, Eds. Agricultural household models. Extensions, applications and policy. Baltimore: The Johns Hopkins University Press 1986: pp. 306-25.

[24] Fall M, Magnac T. How valuable is on-farm work to farmers? Am J Agric Econ 2004; 86: 267-81.

[25] Pretty J, Brett C, Gee D, et al. Policy challenges and priorities for internalising the externalities of modern agriculture. J Environ Plann Manage 2001; 44: 263-83.

[26] Charnes A, Cooper WW, Rhodes E. Measuring the efficiency of decision making units. Eur J Oper Res 1978; 2: 429-44.

[27] Reig-Martínez E, Picazo-Tadeo AJ. Analyzing farming systems with Data Envelopment Analysis: citrus farming in Spain. Agric Syst 2004; 82: 17-30.

[28] Cooper WW, Seiford L, Tone K. Data envelopment analysis: a comprehensive text with models, applications, references and DEA-Solver software. Boston: Springer Verlag 2007.

[29] Gómez-Limón JA, Riesgo L, Arraiza M. Multi-criteria analysis of input use in agriculture. J Agric Econ 2004; 55: 541-64.

[30] Arnalte E, Estruch V. Farming systems in Eastern Spain. In: Avillez F, Ed. The CAP reform and the development of Mediterranean agriculture. Final report, European Research Project FAIR 3, CT 96-1579 2000.

[31] Banker RD, Charnes A, Cooper WW. Some models for estimating technical and scale inefficiencies in Data Envelopment Analysis. Manage Sci 1984; 30: 1078-92.

[32] Shephard RW. The theory of cost and production functions. New Jersey: Princeton University 1970.

[33] Henrichs T, Lehner B, Alcamo J. An integrated analysis of changes in water stress in Europe. Integr Assess 2002; 3: 15-29.

[34] European Environmental Agency. Corine land cover changes (CLC1990-CLC2000) vector by country. Copenhagen 2004. Available from http://www.eea.europa.eu [Accessed on April 16, 2009].

[35] Bates BC, Kundzewicz ZW, Wu S, Palutikof JP, Eds. Climate change and water. Technical paper of the Intergovernmental Panel on Climate Change. Geneva: IPCC Secretariat 2008: p. 210.

[36] European Environment Agency. Climate change and water adaptation issues. Technical report 2/2007. Copenhagen 2007.

[37] Färe R, Grosskopf S, Lovell CAK. Production frontiers. Cambridge: Cambridge University Press 1994.

[38] Simar L, Wilson PW. Estimation and inference in two-stage, semiparametric models of production processes. J Econ 2007; 136: 31 64.

[39] Balcombe K, Fraser I, Latruffe L, Rahman M, Smith L. An application to the DEA double bootstrap to examine sources of efficiency in Bangladesh rice farming. Appl Econ 2008; 40: 191925.

[40] Picazo-Tadeo AJ, Reig-Martínez E. Outsourcing and efficiency: the case of Spanish citrus farming. Agric Econ 2006; 35: 213-22.

[41] Langreo A. La externalización del trabajo agrario y las empresas de servicios a la agricultura. Econ Agraria Recur Nat 2002; 2: 45-67.

[42] Picazo-Tadeo AJ, Reig-Martínez E. Calculating shadow wages for family labor in agriculture: an analysis for Spanish citrus fruit farms. Cah d'Econ Soc Rurales 2005; 75: 6-21. 